\title{
Polychlorinated Biphenyls in Imported Fish
}

\author{
Oiseoje M. Wangboje and Daniel O. Okotie
}

\section{ABSTRACT}

\begin{abstract}
Polychlorinated biphenyls (PCBs) are persistent organic pollutants (POPs) which have been described as organohalogenic and legacy contaminants that are hazardous to both wildlife and man. The paucity of ecotoxicological data on the PCB content in commercially important fish in Benin Metropolis, Nigeria, warranted this research. In this stead, the PCB profile in the Atlantic Herring (Clupea harengus, Family: Clupeidae, mean length=31.59 $\mathrm{cm}$; Mean weight=274.98 $\mathrm{g}$ ) marketed in Benin Metropolis, was determined via Gas Chromatographic technique in order to evaluate its suitability for human consumption and to provide baseline data for this contaminant in commercially important fish species. The summary statistics for the mean concentrations of detectable PCBs in C. harengus ranged from $0.019 \mathrm{mg} / \mathrm{kg}(\mathrm{PCB} 118,156)$ to $0.434 \mathrm{mg} / \mathrm{kg}$ (PCB 126), with a total of $0.581 \mathrm{mg} / \mathrm{kg}(\mathrm{w} / \mathrm{w})$ while the mean concentrations of PCBs in C. harengus by market ranged from $0.012 \mathrm{mg} / \mathrm{kg}$ (PCB 118) at Santana market to $0.526 \mathrm{mg} / \mathrm{kg}$ (PCB 126) at New Benin market with no observed significant difference $(p>0.05)$ in the mean concentrations of PCBs in fish between markets. The toxicity quotient (TQ) values for PCBs in C. harengus ranged from 0.0095 (PCB 118, 156) to 0.217 (PCB 126) while the estimated daily intake (EDI) values in $\mathrm{mg} /$ person/day for $\mathrm{PCBs}$ ranged from 0.00076 (PCB 118, 156) to 0.017 (PCB 126). A toxic equivalency (TEQ) value of 0.04342 while the total PCB content in C. harengus according to market ranged from $0.469 \mathrm{mg} / \mathrm{kg}$ (Santana market) to 0.658 $\mathrm{mg} / \mathrm{kg}$ (Uselu market). The total toxicity of mixtures (TTM) index was 0.291. The PCB levels in fish decreased below International threshold values suggesting suitability for human consumption. Continous monitoring of this fish species for toxic concentrations of PCBs was proferred.
\end{abstract}

Keywords: Clupea harengus, Polychlorinated biphenyls, Toxic equivalency, Toxic quotient.

\section{INTRODUCTION}

Polychlorinated biphenyls (PCBs) are persistent organic pollutants (POPs) which have been described as organohalogenic and legacy/traditional contaminant [1]-[2] and are known to be environmental endocrine-disrupting chemicals [3]-[5]. All PCBs are synthetic and hydrophobic organic chemicals (HOCs) that still abound in sediment and in wildlife including fish [6]. These compounds have continued to be studied for temporal environmental hysteresis because of their prolonged persistence in aquatic ecosystems around the world and inherent hazardous potential to natural aquatic resources [7]. PCBs have been reported to occur in both freshwater and marine ecosystems but are more likely to biomagnify in the marine environment [8]. PCBs alongside other persistent toxic substances (PTSs) are generated via anthropogenic means and enter the marine environment through spills, industrial effluents, river runoff and atmospheric deposition [9]. The principal route of entry of PCBs into man has been reported to be through dietary exposure via the consumption of aquatic species especially fish [10]-[11]. Consumption of aquatic products has also been linked to the polycyclic aromatic hydrocarbon (PAH) burden in man [12]. Health evaluation of workers in the electricity industry regarding
Submitted : January 30, 2021

Published : February 12, 2021

ISSN: $2684-1827$

DOI: $10.24018 /$ ejfood.2021.3.1.232

\section{Oiseoje M. Wangboje *}

Department of Aquaculture and Fisheries Management, University of Benin, Benin City, Nigeria.

(e-mail: oiseoje.wangboje@uniben.edu)

Daniel O. Okotie

Department of Aquaculture and Fisheries Management, University of Benin, Benin City, Nigeria.

(e-mail: okotiedharniel@gmail.com)

*Corresponding Author
PCB exposure has been strongly recommended as a result of potential exposure to dielectric oils, transformer cooling oils and heat exchange fluids that are saturated with PCBs [13]. Around the world, analytical chemists have applied advanced methods for the simultaneous quantification of PCBs in aquatic species including finfish and shellfish in order to rapidly produce reliable data for environmental risk management. For example [14] recently applied ultrasoundassisted cloudy extraction and gas chromatography in tandem with mass spectrometry for this purpose. Enzymatic assays for the assessment of PCBs in water and food has also been applied [15] while direct sample introduction GCMS/MS has been applied to quantify PCBs in mammalian tissue and blood [16]. In addition, human exposure to PCBs has been assessed via hair analysis in China and France [17]. PCBs have been of interest to the scientific community primarily as a result of their carcinogenic, mutagenic and teratogenic properties and potential [18]. [19] observed that extracted oils from fish often contain PCBs that induce toxic effects in humans and that fetuses and infants are especially vulnerable to the dangers of PCBs while [20] reported that imported marine fish species can further expose human populations in other regions to POPs such as PCBs and have the potential for secondary poisoning. PCBs apart from being a direct threat to aquatic 
species, also impact negatively on terrestrial species. For example, [21] observed hazardous levels of these substances in the Habu (Protobothrops flavoviridis) in Okinawa, Japan while [22] discovered very high levels of $\mathrm{PCBs}$ in ruminants on the Island of Curacao, close to Venezuela, which further drives home the menace of PCBs in the environment. According to the Irish Environmental Protection Agency, PCBs persist in the environment because they are dense, extremely stable, nonbiodegradable and resist conventional incineration procedures [23]. Benin City, the Administrative headquarters of Edo State, Nigeria, is aplenty with fish markets; however, there is paucity of ecotoxocological data on the PCB content in commercially important fish species that are widely consumed within the metropolis against the backdrop of the hazardous potential of these substances. On the other hand, such data exist for heavy metals in fish such as the recent research by [24] which reported the heavy metal profile in Scomber scombrus, (Atlantic Mackerel), a sister imported, and marine fish species marketed in Benin City. This research principally focused on the Atlantic Herring (Clupea harengus, Linnaeus, 1758, Family: Clupeidae) which is commonly found in markets within the City. According to the Food and Agriculture Organization of the United Nations (FAO), this fish is one of the most abundant fish species in the world. It is a coastal, benthopelagic, oceanodromous and marine species which feeds on mysid shrimps, small fishes, and a host of zooplankton. It can attain a total length of about $45 \mathrm{~cm}$ though total lengths of about $25 \mathrm{~cm}$ are typical. Countries with the largest catch are Norway and Iceland while the species is common in the North Atlantic, Eastern Atlantic, Western Atlantic and Baltic waters [25]. Fishes from Baltic waters have been reported to usually have very high levels of PCBs [26]. The fish which can attain a weight of over 1.1 $\mathrm{kg}$ is utilized fresh, frozen, dried, salted, smoked, and canned around the world [27]. According to [28] fatty fish such as $C$. harengus, Salmon, Tuna and Trout are highly valued as health foods as they have abundant levels of Omega-3 fatty acids which lower blood pressure, enhance immunity and lower cholesterol. However, in spite of these health benefits, such fish may contain harmful levels of contaminants such as PCBs and would therefore need to be screened [29]-[30]. Therefore, the cardinal objective of this research was to provide baseline data with regard to the PCB profile in the aforesaid fish species in order to guide both current and potential consumers of this aquatic species with regard to food safety.

\section{Materials AND MethodS}

\section{A. Brief Description of the Study Area}

Benin City is gridlocked within Latitude $6^{\circ} 20^{\prime} 0$ North and Latitude $5^{\circ} 38^{\prime} 0$ East (Fig. 1). An extensive description of the study area has been published by [24] and [31]. A pre-survey of markets for the experimental fish species was done in order to pin point suitable market outlets for the convenient collection of samples of fish. The selected markets were Uselu, New Benin, Oba and Santana. Uselu market is located along the ever busy Ugbowo-Lagos highway and it is in close proximity to the University of Benin while New Benin market is situated at the intersection of Mission and New Lagos Roads of the City. It is by far the biggest and busiest of all the selected markets. Oba market is located along the Ring Road axis of the City while Santana market is located along the Sapele Road axis of the City.

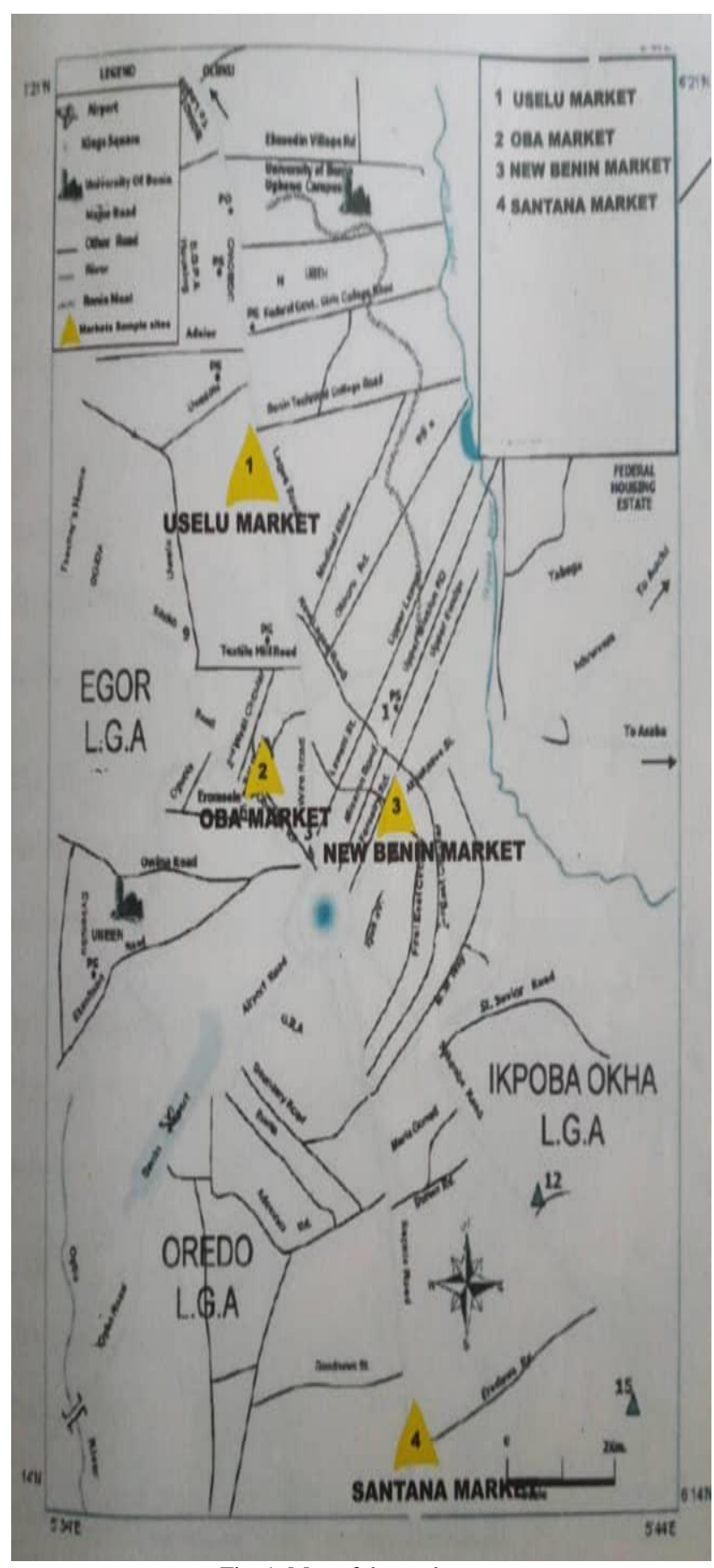

Fig. 1. Map of the study area.

Samples of fish were purchased from the aforesaid markets between June and November 2019. They were placed in new polythene bags, sealed, labeled and moved to the laboratory in a Thermolineo ${ }^{\circledR}$ ice chest within 24 hours.

\section{B. Laboratory Activities}

The identity of fish species $(n=24)$ was confirmed using the Food and Agriculture Organization of the United Nations (FAO) species identification/fact sheet [25]. Total 
length $(\mathrm{cm})$ measurements were taken using a measuring board while weight $(\mathrm{g})$ of fish samples were measured using an electronic Scale (Mettler ${ }^{\circledR}$ PM4800 Delta Range). The mean total length was $31.59 \mathrm{~cm}$ while the mean weight was $274.98 \mathrm{~g}$ (Table 1). All reagents and chemicals used were of analytical grade (BDH, Poole, England and Sigma, USA). All glassware was soaked in detergent and then rinsed alternately with running tap water and distilled water. Summarily, ten (10) g of muscle tissue was excised from the flanks with a stainless steel lancet and ground with anhydrous sodium sulphate until a completely dry homogenate was obtained. The extraction of PCB from fish tissue was performed according to standard procedures [32]. The extract was concentrated to $2 \mathrm{ml}$ with a rotary evaporator (rotovap) at $40{ }^{\circ} \mathrm{C}$. The concentrated extract was thereafter used for clean-up and for gravimetric lipid determination. Clean-up of extracts was done in line with the method by [33] while a Perkin ${ }^{\circledR}$ model 5890 gas chromatograph equipped with $\mathrm{Ni} 63$ electron capture detector was used for quantification of PCBs. The quality control was performed by regular analyses of procedural blanks and blind duplicate samples along with random injection of standards and solvent blanks. A similar approach of analysis was earlier followed by [18].

\section{Toxic Equivalency (TEQ) for PCBs}

The toxic equivalency (TEQ) for PCBs according to [26][34] is expressed below:

$$
\mathrm{TEQ}=\sum \mathrm{PCBi} * \mathrm{TEF}
$$

where: TEQ $=$ Toxic equivalency. $\mathrm{PCBi}=\mathrm{PCB}$ concentration in fish.

$\mathrm{TEF}=$ Toxic equivalency factor for specific Congener.

\section{Total Toxicity of Mixtures (TTM) Index for PCBs}

Whether or not a mixture of chemical contaminants in a particular medium exceeds the quality guideline value for that medium, may be evaluated by applying the TTM index [35].

\section{$\mathrm{TTM}=\Sigma(\mathrm{C} 1 / \mathrm{GV} 1)$}

where: $\mathrm{C} 1=$ Concentration of the 'ith' component of mixture;

GV1= Guideline value for the 'ith' component; TTM $>1=$ The mixture has exceeded the Guideline value.

\section{E. Statistical Protocol}

GENSTAT ${ }^{\circledR}$ computer software (Version 12.1 for Windows) was used for statistical analysis. Data were subjected to Analysis of variance (ANOVA) to determine significant differences between mean values of PCBs while significance means $(\mathrm{p}<0.05)$ were separated with Duncan multiple range test (DMRT).

\section{F. Estimation of Daily Intake (EDI) of PCBs by Man}

The EDI is expressed below according to [18]. where: $40 \mathrm{~g} /$ person/day = Estimated average fish consumption in the Niger Delta belt, Nigeria; $\mathrm{CPCB}=\mathrm{PCB}$ concentration $(\mathrm{mg} / \mathrm{kg})$ in fish.

\section{G. Toxic/ hazard quotient (TQ) for PCBs}

The TQ expresses the possibility of a chemical contaminant being an ecological risk or a contaminant of potential ecological concern [36].

\section{RESULTS}

The summary statistics for levels $(\mathrm{mg} / \mathrm{kg})$ of detectable PCBs in Clupea harengus ranged from 0.019 (PCB 118, PCB 156) to 0.434 (PCB 126), with a total PCB $\left(\mathrm{TPCB}_{6}\right)$ value of $0.581 \mathrm{mg} / \mathrm{kg}(\mathrm{w} / \mathrm{w})$ as presented in Table 2 . The PCB content $(\mathrm{mg} / \mathrm{kg})$ in $C$. harengus according to market points ranged from 0.012 (PCB 118) at Santana market to 0.526 (PCB 126) at New Benin market, with no observed significant differences $(p>0.05)$ in the mean concentrations of PCBs in fish between markets (Table 3) while the PCB content $(\mathrm{mg} / \mathrm{kg})$ in fish according to period ranged from 0.012 (PCB 118) in June and July, PCB 153 in June to 0.556 (PCB 126) in October, with an observed significant difference $(p<0.05)$ in the mean concentrations of PCB 118 in fish between months as shown in Table 4. The estimated daily intake (EDI) values (mg/person/day) for PCBs ranged from 0.00076 (PCB 118, 156) to 0.017 (PCB 126) as presented in Fig. 2 while the Toxic quotient (TQ) values ranged from 0.0095 (PCB 118, 156) to 0.217 (PCB 126) as shown in Fig. 3. The PCB quota $(\%)$ in fish ranged from 3.27 (PCB 118, 156) to 74.69 (PCB 126) as presented in Fig.4 while the TPCB content $(\mathrm{mg} / \mathrm{kg})$ in fish according to market points ranged from 0.469 at Santana market to 0.658 at Uselu market (Fig. 5). The observed total toxicity of mixtures (TTM) value was 0.291 (Fig. 6) while a toxic equivalency (TEQ) value of 0.04342 was recorded (Fig. 7). Finally, PCB 126 accounted for $99.95 \%$ of the total TEQ value as shown in Fig. 8.

TABLE 1: MORPHOMETRIC MEASUREMENTS FOR CLUPEA HARENGUS

\begin{tabular}{ccc}
\multicolumn{3}{c}{ MARKETED IN BENIN CITY } \\
\hline Period & Mean Length $(\mathrm{cm})$ & Mean Weight $(\mathrm{g})$ \\
\hline June, 2019 & 28.21 & 252.35 \\
July, 2019 & 31.82 & 283.44 \\
August, 2019 & 29.48 & 275.27 \\
September, 2019 & 35.10 & 297.43 \\
October, 2019 & 28.47 & 256.65 \\
November, 2019 & 36.45 & 284.71 \\
Grand Mean & 31.59 & 274.98 \\
\hline
\end{tabular}

TABLE 2: SUMMARY STATISTICS FOR PCB LEVELS (MG/KG) IN CLUPEA

\begin{tabular}{cccc}
\multicolumn{4}{c}{ HARENGUS } \\
\hline $\begin{array}{c}\text { PCB } \\
\text { Congener }\end{array}$ & Mean & Min. & Max. \\
\hline PCB 114 & 0.024 & 0.010 & 0.07 \\
PCB 118 & 0.019 & 0.009 & 0.091 \\
PCB 126 & 0.434 & 0.056 & 0.791 \\
PCB 138 & 0.062 & 0.012 & 0.112 \\
PCB 153 & 0.023 & 0.006 & 0.065 \\
PCB 156 & 0.019 & 0.011 & 0.032 \\
\hline
\end{tabular}

$$
\frac{40 \frac{\mathrm{g}}{\text { person }}}{\text { day }} * C P C B / 1000 \mathrm{~g} / \mathrm{kg}
$$


European Journal of Agriculture and Food Sciences www.ejfood.org

TABLE 3: MEAN LEVELS OF PCB (MG/KG) IN CLUPEA HARENGUS ACCORDING TO MARKET POINTS

\begin{tabular}{ccccccc} 
Market & PCB & PCB & PCB & PCB & PCB & PCB \\
point & 114 & 118 & 126 & 138 & 153 & 156 \\
\hline Uselu & $0.037^{\mathrm{a}}$ & $0.014^{\mathrm{a}}$ & $0.524^{\mathrm{a}}$ & $0.049^{\mathrm{b}}$ & $0.018^{\mathrm{b}}$ & $0.016^{\mathrm{a}}$ \\
New- & $0.023^{\mathrm{a}}$ & $0.018^{\mathrm{a}}$ & $0.526^{\mathrm{a}}$ & $0.030^{\mathrm{b}}$ & $0.017^{\mathrm{b}}$ & $0.022^{\mathrm{a}}$ \\
Benin & & & & & $0.036^{\mathrm{a}}$ & $0.021^{\mathrm{a}}$ \\
Oba & $0.016^{\mathrm{a}}$ & $0.023^{\mathrm{a}}$ & $0.372^{\mathrm{a}}$ & $0.084^{\mathrm{a}}$ & $0.036^{\mathrm{a}}$ & $0.020^{\mathrm{a}}$ \\
Santana & $0.019^{\mathrm{a}}$ & $0.012^{\mathrm{a}}$ & $0.314^{\mathrm{a}}$ & $0.085^{\mathrm{a}}$ & $0.019^{\mathrm{b}}$ & 0.5 \\
\multicolumn{5}{l}{ Means on the same column with similar superscripts are not significantly }
\end{tabular}
different $(p>0.05)$

TABLE 4: MEAN LEVELS OF PCB (MG/KG) IN CLUPEA HARENGUS ACCORDING TO PERIOD

\begin{tabular}{ccccccc}
\multicolumn{7}{c}{ ACCORDING TC PERIOD } \\
\hline \multirow{2}{*}{ Period } & PCB & PCB & PCB & PCB & PCB & PCB \\
& 114 & 118 & 126 & 138 & 153 & 156 \\
\hline June, 2019 & $0.015^{\mathrm{a}}$ & $0.012^{\mathrm{b}}$ & $0.351^{\mathrm{a}}$ & $0.058^{\mathrm{a}}$ & $0.012^{\mathrm{a}}$ & $0.014^{\mathrm{a}}$ \\
July, 2019 & $0.019^{\mathrm{a}}$ & $0.012^{\mathrm{b}}$ & $0.316^{\mathrm{a}}$ & $0.036^{\mathrm{a}}$ & $0.013^{\mathrm{a}}$ & $0.015^{\mathrm{a}}$ \\
Aug. 2019 & $0.020^{\mathrm{a}}$ & $0.014^{\mathrm{b}}$ & $0.458^{\mathrm{a}}$ & $0.060^{\mathrm{a}}$ & $0.019^{\mathrm{a}}$ & $0.018^{\mathrm{a}}$ \\
Sept. 2019 & $0.025^{\mathrm{a}}$ & $0.014^{\mathrm{b}}$ & $0.456^{\mathrm{a}}$ & $0.061^{\mathrm{a}}$ & $0.023^{\mathrm{a}}$ & $0.019^{\mathrm{a}}$ \\
Oct. 2019 & $0.029^{\mathrm{a}}$ & $0.013^{\mathrm{b}}$ & $0.556^{\mathrm{a}}$ & $0.089^{\mathrm{a}}$ & $0.036^{\mathrm{a}}$ & $0.029^{\mathrm{a}}$ \\
Nov. 2019 & $0.034^{\mathrm{a}}$ & $0.049^{\mathrm{a}}$ & $0.466^{\mathrm{a}}$ & $0.068^{\mathrm{a}}$ & $0.033^{\mathrm{a}}$ & $0.021^{\mathrm{a}}$ \\
\hline \multicolumn{7}{l}{ Means on the same column with similar superscripts are not significantly } \\
different (p>0.05.
\end{tabular}

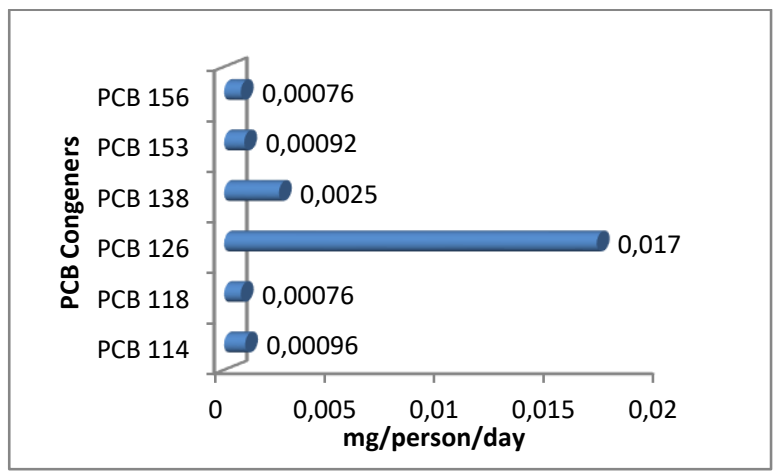

Fig. 2. Estimated daily intake (EDI) values for PCBs via the potential consumption of Clupea harengus.

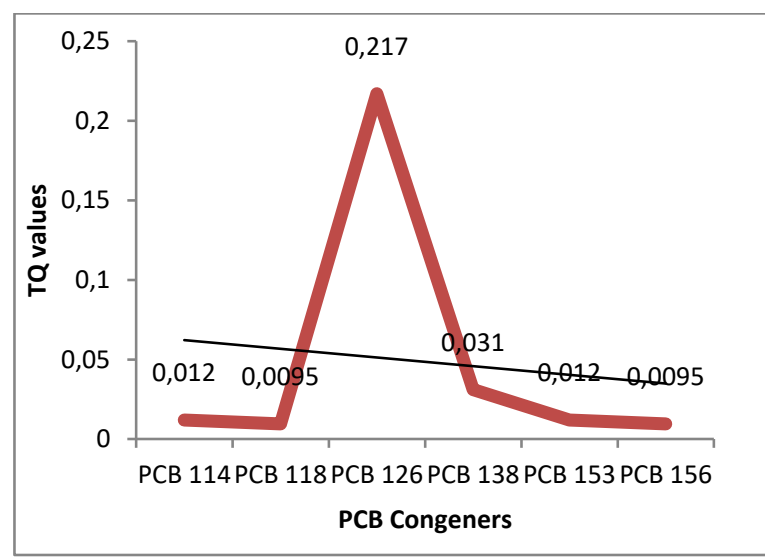

Fig. 3. Toxic quotient (TQ) values for PCB Congeners in Clupea harengus.

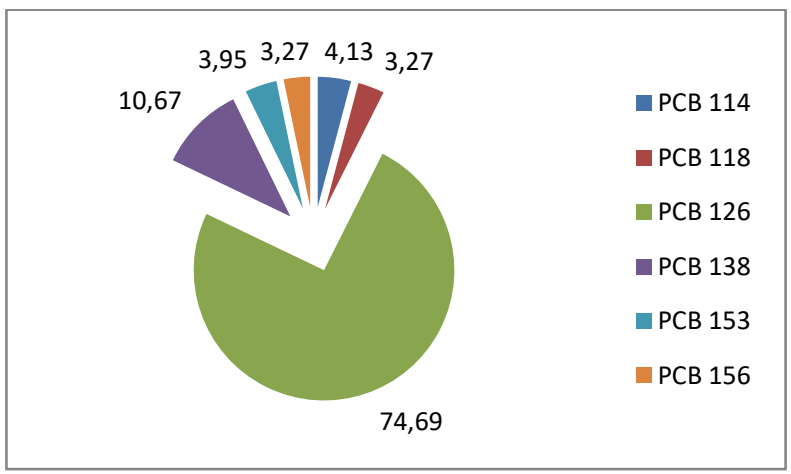

Fig. 4. Quota (\%) of PCB Congeners in Clupea harengus marketed in Benin City.

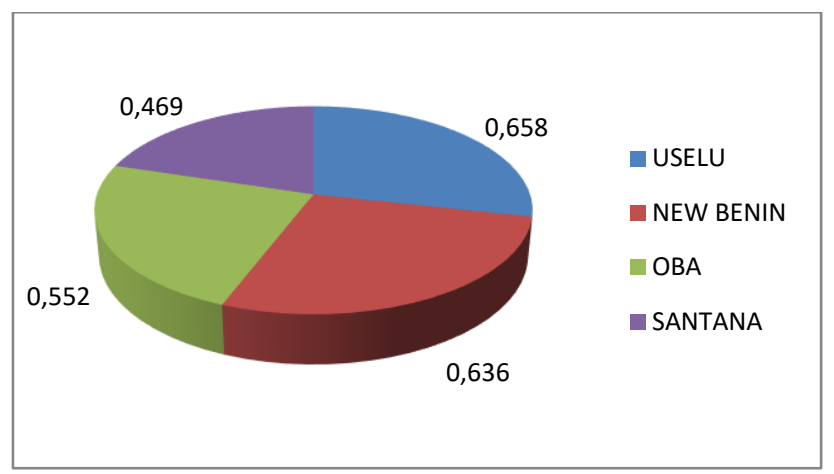

Fig. 5. Total PCB content (mg/kg) in Clupea harengus according to market points.

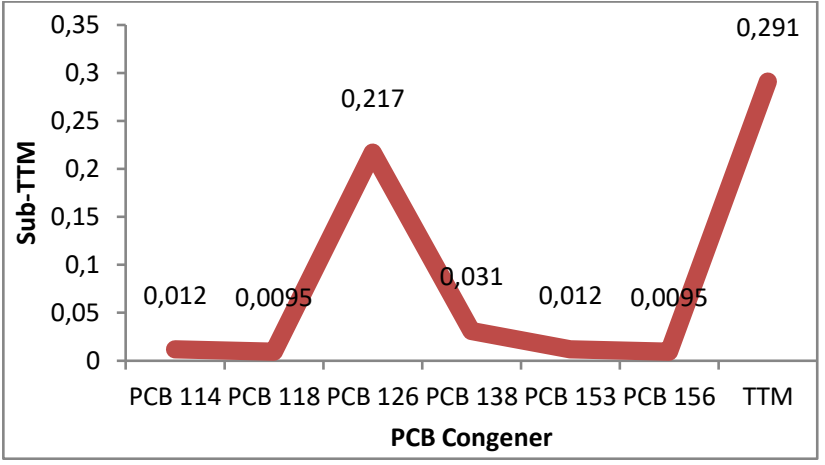

Fig. 6. The TTM index for PCBs in Clupea harengus marketed in Benin City.

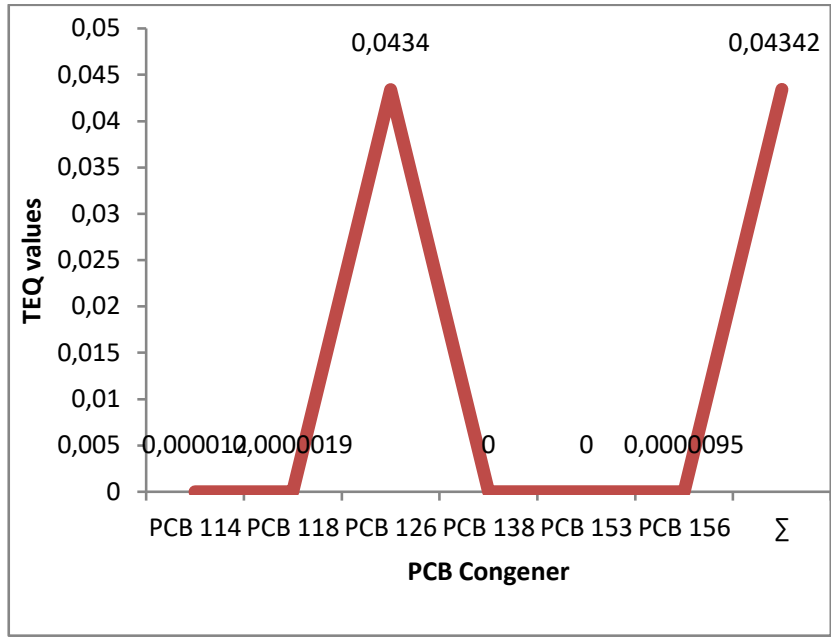

Fig. 7. The TEQ values for PCBs in Clupea harengus marketed in Benin City.

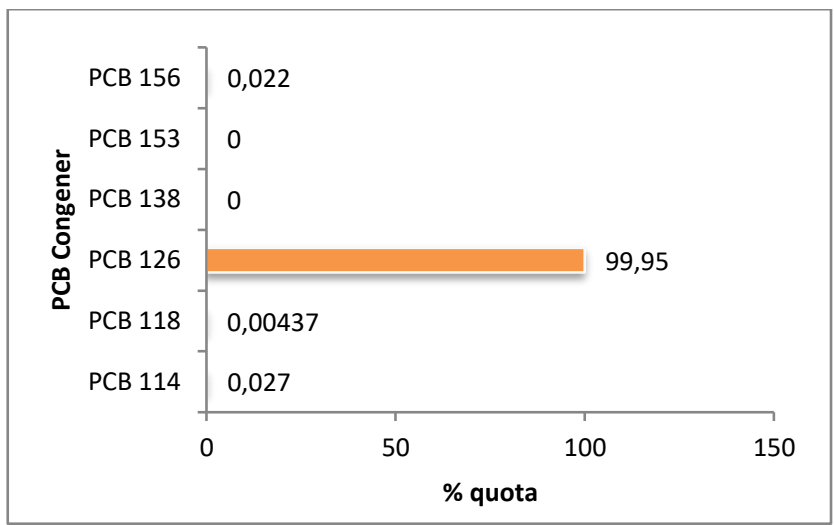

Fig. 8. Specific PCB Congener quota in the overall TEQ value. 


\section{DISCUSSION}

The detectable PCB Congeners in $C$. harengus in this research had a rank profile of PCB $126>$ PCB $138>$ PCB $114>$ PCB $153>$ PCB 118/156 with PCB 126 having a dominating quota of $74.69 \%$ of the total PCB $\left(\mathrm{TPCB}_{6}\right)$ burden of $0.581 \mathrm{mg} / \mathrm{kg}$, clearly giving an indication that PCB 126 accumulated more in this fish species compared to the other Congeners. The respective alternative IUPAC names for these Congeners are: 3, 3', 4, 4' 5-PentaCB, 2, 2' 3, 4, 4', 5'-HexaCB, 2, 3, 4, 4' 5-PentaCB, 2, 2' 4, 4', 5, 5'HexaCB, 2, 3' 4, 4' 5-PentaCB and 2,3, 3', 4, 4', 5HexaCB. According to [37] there are 209 PCB Congeners in existence but only about 130 or less are likely to be found in commercial food supplies worldwide as these substances still persist owing to their presence in some industrial systems and hazardous waste materials. The lipophilic biochemical attribute of PCBs may explain their presence in C. harengus as the fish is a fatty species. It is on this premise that Fish Advisories usually recommend the trimming of fat from fish as PCBs readily concentrate in such fatty or adipose tissue [28]. As observed by [38] the lipophilicity of PCBs can to a great extent influence their mobilization within aquatic species. In addition, the cell lipid content in the host organism could also affect the accumulation pattern of PCBs [39]. [40] reported that the highest PCB concentrations in food are in those sourced from fish with a high fat content and that such food is actually the main vehicle of contamination for humans. Furthermore, levels of PCBs have been reported to be much higher in aquatic species whose muscles contain more fat [41]. With regard to the $\mathrm{TPCB}_{6}$ in $C$. harengus [42] reported lower TPCB values of $0.1 \mathrm{mg} / \mathrm{kg}, 0.20 \mathrm{mg} / \mathrm{kg}, 0.05 \mathrm{mg} / \mathrm{kg}$ and $0.15 \mathrm{mg} / \mathrm{kg}$ in samples of Bream (Sparus aurata), Perch (Perca fluviatilis), Roach (Rutilus rutilus) and Northern Pike (Esox lucius) respectively from the Lakes of Warmia and Mazury Regions in Poland. On the other hand [43] reported much higher TPCB values of $1.58 \mathrm{mg} / \mathrm{kg}$ and 1.54 $\mathrm{mg} / \mathrm{kg}$ in samples of the Arctic char (Salvielinus alpinus) and Pink Salmon (Oncorhynchus gorbuscha) respectively from the Nenets Autonomous Okrug region of Russia. The authors however recorded a comparable TPCB value of $0.32 \mathrm{mg} / \mathrm{kg}$ in the Northern Pike (Esox lucius) from the same region. [18] observed a higher TPCB value of $0.93 \mathrm{mg} / \mathrm{kg}$ in the Atlantic Mackerel (Scomber scombrus) marketed within Asaba, Delta State, Nigeria. The TPCB values according to market points was lowest and highest at Santana and Uselu markets respectively, suggesting that prospective buyers of $C$. harengus are more likely to be exposed to a lower PCB burden from fish purchased in the former market. However, there was no significant difference $(p>0.05)$ in the mean concentrations of PCBs in fish between the various market points, suggesting that such fish may have come from the same supplier or source. Generally, there was no observed significant difference ( $>0.05)$ in the mean concentration of PCBs in fish between months, the only exception being PCB 118, suggesting that the variation in the PCB levels in fish between months was negligible. Not surprising, the lowest and highest EDI values were observed for PCB 118/156 and PCB 126 respectively, since the lowest and highest mean levels of PCBs in C. harengus were recorded for these contaminants.
The observed TQ values for non-oncological risk were all below unity for all the detected PCBs suggesting a non-risk to potential consumers of $C$. harengus. The vertical trend line for the TQ values indicated that all the available PCB Congeners were on par with the exception of PCB 126. This observation again buttresses the dominance of PCB 126 in C. harengus. The $\mathrm{TPCB}_{6}$ in fish in this research revealed that International maximum limits were not surpassed indicating that $C$. harengus is safe for consumption, an assertion that has been supported by the TTM value of 0.291, which did not exceed unity. According to [44] the United States Food and Drug Administration (FDA) has recommended a threshold of $2.0 \mathrm{mg} / \mathrm{kg}$ for PCBs in fish, which was adopted and applied in this research. The FDA has also recommended tolerance intakes of between 0.2 and $3.0 \mathrm{mg} / \mathrm{kg}$ for several food items and $10 \mathrm{mg} / \mathrm{kg}$ for paper food-packaging materials. The TEQ value for PCBs in this research (0.04342) was almost entirely accounted for by PCB 126, once again highlighting the dominance and potential potency of this Congener. It would thus appear that PCB 126 is the Congener that needs to be taken into serious consideration as it clearly has the potential to be of risk in future. According to the United States Environmental Protection Agency (USEPA), PCB 126 is a dioxin-like PCB (DL-PCB) and is one of the most toxic PCB Congeners available [45]. Such dioxin-like substances directly impair endothelial functions and can be linked to coronary artherosclerosis in man [46].

\section{CONCLUSION}

The PCB profile in $C$. harengus revealed that this particular aquatic species is relatively safe for consumption by the public. Baseline data has also been presented which could be used as a reference point for future research on PCBs and other POPs and legacy contaminants in commercially important fish species. Borne out of the findings from this scientific work, it is proffered that this species and other sister imported brands be monitored for PCB content in order to assure the consuming public of adequate food safety arising from the consumption of such natural aquatic resources. It also suggested that a longer period of sampling be adopted in future studies in other to establish tangible trend lines that would be useful in ecological risk management regimes and prediction systems.

\section{ACKNOWLEDGEMENT}

The Authors are grateful to the Faculty of Agriculture, University of Benin, Nigeria, for providing general laboratory space; to Splendidstan Environmental Laboratory, Benin City, Nigeria for the use of their Gas Chromatographic equipment.

\section{REFERENCES}

[1] C.A. DeWit, R. Bossi, R. Dietz, A. Dreyer, S. Faxneld, S.E. Garbus, P. Hellstrom, J. Koschorreck, N. Lohmann, A. Roos, U. Sellstrom, C Sonne, G. Treu, K. Vorkamp, B. Yuan, and I. Eulaers, "Organohalogen compounds of emerging concern in Baltic Sea biota: 
Levels, biomagnification potential and comparisons with legacy contaminants," Environment International, Vol. 144, 2020. DOI.org/10.1016/j.envint.2020.106037.

[2] M. Parolini, S. Panseri, F.H. Gaeta, F. Ceriani, B. DeFelice, M. Nobile, G. Mosconi, T. Rafoss, F. Arioli, and L. M. Chiesa, "Legacy and emerging contaminants in dermersal fish species from Southern Norway and implications for food safety." Foods, Vol. 9:1108, 2020. DOI:10.3390/foods9081108.

[3] W.L. Wu, S.J Deng, H. Zhou, H. Liang, X.F Yang, and J. Wen, "Levels, Congener profile and dietry intake assessment of polychlorinated dibenzofurans and dioxin-like polychlorinated biphenyls in beef, freshwater fish and pork marketed in Guangdong Province, China," Science of the Total $\begin{array}{llll}\text { Environment, } & \text { Vol. 615, pp. 412-421,2020. }\end{array}$ DOI.org/10.1016/j.scitotenv.2017.09.273.

[4] X. Hua, H. Jiang, N. Guo, Y. Du, X. Yuan, T. Deng, X. Teng, Y. Yao, and Y. Li, "Effects of prepubertal exposure to Aroclor-1221 on reproductive development and transcriptional gene expression in female rats," Reproductive $\quad 2020$. DOI.org/10.1007/s43032-020-00290-8.

[5] S. Kar, P. Sangem, N. Anusha, and B. Senthilkumaran, "Endocrine disruptors in teleosts: Evaluating environmental risks and biomarkers," Aquaculture and Fisheries, 2020. DOI.org/10.1016/j.aaf.2020.07.013.

[6] M. Llorca, M. Abalos, A. Vega-Herrera, M.A. Adrados, E. Abad, and M. Farre, "Adsorption and desorption behavior of polychlorinated biphenyls onto microplastics surfaces in water/sediment systems." Toxics. Vol. 8, No. 59, 2020. DOI:10.3390/toxics8030059.

[7] R.A. Hites, D.C. Lehman, A. Salamova, and M. Venier, "Temporal environmental hysteresis: A definition and implication for polybrominated diphenyl ethers," Science of the Total Environment, 2020. DOI.org/10.1016/j.scitotenv.2020.141849.

[8] D.K. Prince, S.D. Taylor, and C. Angelini, "A global cross-system meta-analysis of polychlorinated biphenyl biomagnification," Environmental Science and Technology, 2020. DOI.org/10.1021/acs.est.9b07693.

[9] Y. An, S. Hong, S.J. Yoon, S. J. Cha, K. Shin, and J.S. Khim, J.S. "Current contamination status of traditional and emerging persistent toxic substances in the sediments of Ulsa Bay, South Korea," Marine Pollution Bulletin. 2020, DOI.org/10.1016/j.marpolbul.2020.111560.

[10] M. Pruvost-Couvreur, B. LeBizec, I. Margaritis, J. Volatier, C. Bechaux, and G. Riviere, "Impact of dietary guidelines on lifetime exposure to chemical contaminants: Divergent conclusions for two bioaccumulative substances." Food and Chemical Toxicology. 2020. DOI.org/10.1016/j.fct.2020.111672.

[11] P. Saktrakulkla, T. Lan., J. Hua, R.F., Marek, P.S. Thorne, and K.C. Hornbuckle, "PCBs in Food," Environmental Science and Technology, 2020. DOI.org/10.1021/acs.est.0c036632

[12] Q. Wang, L. Chu, F. Peng, J. Li., H. Chen, and L. Jin, "Contribution of aquatic products consumption to total human exposure to PAHs in Eastern China: The source matters," Environmental Pollution. 2020. DOI.org/10.1016/j.envpol.2020.115339.

[13] B.S. Avila, C. Ramirez, E. Tellez-Avila, and D. Combariza, "Occupational exposure to polychlorinated biphenyls (PCBs) in workers at companies in the Colombian electricity sector," International Journal of Environmental Health Research, 2020. DOI.org/10.1080/09603123.2020.1806213.

[14] J. Lee, S.Y. Lee, K. Park, H. Lim, and H. Shin, "Simultaneous determination of PCBs, OCPs and PAHs in mussel by ultrasoundassisted cloudy extraction and gas chromatography-tandem mass spectrometry," Food Additives and Contaminants Part A. 2020. DOI.org/1080/19440049.2020.1798029.

[15] A.E. Artabe, H. Cunha-Silva, and A. Barranco, "Enzymatic assays for assessment of toxic effects of halogenated organic contaminants in water and food. A review," Food and Chemical Toxicology, 2020. DOI.org/10.1016/j.fct.2020.111677.

[16] A. Baumer, B.I. Escher, J. Landmann, and N. Ulrich, "Direct sample introduction GC-MS/MS for quantification of organic chemicals in mammalian tissues and blood extracted with polymers without cleanup," Analytical and Bioanalytical Chemistry, 2020. DOI.org/10.1007/s00216-020-02864-6.

[17] F. Peng, E.M. Hardy, R. Beranger, S. Mezzache, N. Bourokba, P. Bastien, J. Li., C. Zaros, C. Chevrier, P. Palazzi, J. Soeur, and B.M.R. Appenzeller, "Human exposure to PCBs, PBDEs and biphenols revealed by hair analysis: A comparison between two adult populations in China and France," Environmental Pollution., 2020. DOI.org/10.1016/j.envpol.2020.115425.

[18] O.M. Wangboje, and O. Obotha-Adigo, "Residual levels of polychlorinated biphenyls (PCBs) in the Atlantic Mackerel (Scomber scombrus, Linnaeus, 1758) marketed within a Niger Delta
Community," European Journal of Agriculture and Food Sciences, 2020. DOI.org/10.24018/ejfood.2020.2.4.93.

[19] Y. Matsuo, K. Nakai, I. Sakuma, K. Akutsu, N. Tatsuta, M. Ishiyama, T. Higuchi, N. Ryuda, and D. Ueno, "Estimation of PCB intake through fish oil derived dietary supplements and prescription drugs in the Japanese population," Journal of Food Quality and Hazards Control, Vol. 6, pp. 146-152, 2019. DOI:10.18502/jfhc.6.4.1992.

[20] D.C.G. Muir, "Toxic chemical exposure from global fish trade," Nature Food, Vol. 1, p. 259, 2020. DOI.org/10.1038/s43016-0200080-3.

[21] Y. Tashiro, A. Goto, and S. Tanabe, "Contamination of Habu (Protobothrops flavoviridis) in Okinawa, Japan by persistent organochlorine chemicals," Environmental Science and Pollution Research, 2020.DOI.org/10.1007/s11356-020-10510-y.

[22] R.L.A.P. Hoogenboom, G. Ten-Dam, S.P.J. Van-Leeuwen, H. VanEgmond, J. Nicolina, and A.J.S. Dwarkasing, Chemosphere, 2020. DOI.org/10.1016/j.chemosphere.2020.128057.

[23] Environmental Protection Agency, "Parameters of Water Quality. Interpretation and Standards," EPA, Ireland. 133 pp., 2001.

[24] O.M. Wangboje, S. Akaehomen, and M. Erhayimwen, "Human health risk assessment in relation to heavy metals in the Atlantic mackerel (Scomber scrombrus, L., 1758) sold in some major markets in Benin City, Nigeria," Tropical Journal of Natural Product Research, Vol. 1, No. 1, pp. 32-38, 2017. DOI.org/10.26538/tjnpr/v1i1.6.

[25] Food and Agriculture Organization of the United Nations, "FAO species fact sheet-Clupea harengus (Linnaeus, 1758).,"www.fao.org/fishery/species/2886/en Accessed 20 June 2019.

[26] Commission Regulation, “Amending Regulation (EC) No 1881/2006. Setting maximum levels for certain contaminants in foodstuffs," No 629/2008 of 2 July 2008.

[27] Fish Base, "Clupea harengus, Linnaeus 1758, Atlantic herring,"www.fishbase.se/summary/clupea-harengus.html Accessed 26 August 2020.

[28] Missouri Fish Advisory, "A guide to eating Missouri fish,” Missouri Department of Health and Senior Services (DHSS) and Bureau of Environmental Epidemiology (BEE), Missouri, U.S.A. 20 pp., 2020.

[29] New Jersey Freshwater Fishing Digest, "A Summary of Regulations and Freshwater Fisheries Management Information, Freshwater Fishing Season Dates and Limits,” New Jersey Fisheries and Wildlife Department, U.S.A. 48 pp., 2020.

[30] M.J Dellinger, R. Anguzu, N. Pingatore, and M. Ripley, "Riskbenefit modeling to guide health research in collaboration with Great Lakes fish consuming Native American communities," Journal of Great Lakes Research, 2020. DOI.org/10.1016/j.jglr.2020.08.003.

[31] O.M. Wangboje, O.T. Ekundayo, E.J. Osasehi1, M. Erhayimwen, and U.I. Efenudu, "Human risk associated with potential exposure to heavy metals in a Gadoid fish species from selected markets in Benin City, Nigeria," Tropical Freshwater Biology, Vol. 28, No. 2, pp.13-31, 2019. DOI.org/10.4314/tfb.v28i2.2.

[32] United States Environmental Protection Agency, "Method 8082: PCBs by Gas Chromatography," USEPA, Washington, DC, USA., 1996.

[33] E. Kampire, G. Rubidge, and J.B. Adams, "Distribution of polychlorinated biphenyl residues in several tissues of fish from the North End Lake, Port Elizabeth, South Africa," Water SA., Vol. 41, No. 4, pp. 559-570, 2015. DOI.org/10.4314/wsa.v41i4.16.

[34] New York State Department of Environmental Conservation, "Polychlorinated Biphenyls (PCBs) in five fish species from the New York-New Jersey Harbor Estuary," NYSDEC, Division of Fish, Wildlife and Marine Resources, 397pp., 2004.

[35] ANZECC/ARMCANZ, "Australian and New Zealand Guidelines for fresh and marine water quality," Vol. 1: National Water Quality Management Strategy, Paper No. 4. Australian and New Zealand Environment and Conservation Council / Agriculture and Resource Management Council of Australia and New Zealand, Canberra, Australia. 314 pp., 2000.

[36] O.M. Wangboje, and J. Okpobo, "Potential carcinogenic risk from polycyclic aromatic hydrocarbons in selected smoked fish species from a typical rural market in West Africa," International Journal of Research and Reviews in Applied Sciences, Vol. 41, No. 1, pp. 1-9, 2019.

[37] Codex Alimentarius Commission, "Joint FAO/WHO Food Standards Programme, Codex Committee on contaminants in foods," Fifth Session, The Hague, The Netherlands, 21-25 March, 2011. Document Number CF/5 INF/1. 90 pp., 2011.

[38] C. Louis, A. Covaci, D.E. Crocker, and C. Debier, C. "Lipophilicity of PCBs and fatty acids determines their mobilization from blubber of weaned northern elephant seal pups," Science of the Total 
Environment, Vol. 541, pp. 599-602, 2016. DOI:10.1016/j.scitotenv.2015.09.094.

[39] S. Bourez, C.V. Daelen, S. LeLay, J. Poupaert, Y. Larondelle, J. Thome, Y. Schneider, I. Dugail, and C. Debier, "The dynamics of accumulation of PCBs in cultured adipocytes vary with the cell lipid content and the lipophilicity of the Congener," Toxicology Letters, Vol. 216, No. 1, pp. 40-46, 2013. DOI:10.1016/j.toxlet.2012.09.027.

[40] The French Agency for Food Environment and Occupational Health and Safety, "PCBs identy sheet," The French Agency for Food Environment and Occupational Health and Safety (ANSES), MaisonAlfort Cedex, France. 14 pp., 2016.

[41] S. Mikolajczyk, M. Warenik-Bany, S. Maszewski, and M. Pajurek, "Farmed fish as a source of dioxins and PCBs for Polish consumers," Journal of Veterinary Research, 2020. DOI:10.2478/jvetres-20200054.

[42] M. Dymkowska-Makesa, A. Plawgo, and Z. Walczak, "Levels of polychlorinated biphenyls (PCB) in fish from the Lakes of the Warmia and Mazury Region." Journal of Environmental Science and Engineering A 1, pp. 250-255, 2012.

[43] D. Lakhmanov, Y. Varakina, A. Aksenov, T. Sorokina, N. Sobolev, D. Kotsur, E. Plakhina, V. Chashchin, and Y. Thomassen, "Persistent organic pollutants (POPs) in fish consumed by the indigenous peoples from Nenets Autonomous Okrug," Environments, Vol. 7, DOI.10.3390/environments7010003.

[44] Agency for Toxic Substances and Disease Registry, "Polychlorinated biphenyls (PCBs) toxicity. What Standards and Regulations exist for PCB exposure," Health and Medicine Education, ATSDR, Atlanta, U.S.A., 2016. www.atsdr.cdc.gov/csem/csem.asp Accessed 27 August 2020.

[45] United States Environmental Protection Agency, "Polychlorinated biphenyls (PCBs): Toxicity and Exposure Assessment for Children's Health (TEACH)," USEPA, 30 pp.,2009.

[46] C. Dornat-Vargas, B. Moreno-Franco, M. Laclaustra, H. SandovalInsausti, E. Jarauta, and P. Guallar-Castillon, "Exposure to dietary PCBs and dioxins and its relationship with subclinical coronary artherosclerosis: The Aragon worker's health study," Environment International, 2020. DOI.org/10.1016/j.envint.2019.105433.

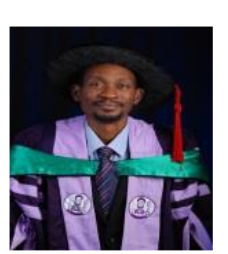

Wangboje, M. Oiseoje is a Senior Lecturer and Researcher in the Department of Aquaculture and Fisheries Management, Faculty of Agriculture, University of Benin, Benin City, Nigeria. Dr. Wangboje was born in Zaria, Kaduna State, Nigeria and received his tertiary education at the University of Benin. He holds a B.Sc. Degree in Zoology (Second Class, Upper)-1995; M.Sc. Degree in Fisheries (1999) and a Ph. D in Fisheries (2013). He specializes in Fish biology and Ecotoxicology /Ecological Risk Assessment. He teaches water pollution, limnology, fish biology, aquatic flora and fauna, fish parasites and disease, Oceanographic techniques and land use planning. His publications span across Local, National and International peer-reviewed journals of high repute, including Asian Journal of Environment and Ecology, International Journal of Fisheries and Aquatic Studies, Ethiopian Journal of Environmental Studies and Management, International Journal of Applied Science and Research and International Journal of Research and Reviews in Applied Sciences and the European Journal of Agriculture and Food Science. He is a member of the Fisheries Society of Nigeria (FISON) and the Global Youth Network on Biodiversity.

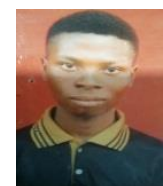

Okotie, O. Daniel was born on the $4^{\text {th }}$ of September 1995. $\mathrm{He}$ is a budding Ecotoxicologist in the Department of Aquaculture and Fisheries Management, University of Benin, Benin City, Nigeria, under the supervision of Dr. O.M. Wangboje, the Lead Investigator. 